Article

\title{
Physicochemical Properties, Antioxidant and Cytotoxic Activities of Crude Extracts and Fractions from Phyllanthus amarus
}

\author{
Van Tang Nguyen ${ }^{1,2, *}$, Jennette A. Sakoff ${ }^{3}$ and Christopher J. Scarlett ${ }^{1}$ \\ 1 School of Environmental and Life Sciences, Faculty of Science and Information Technology, University of \\ Newcastle, Ourimbah, NSW 2258, Australia; C.Scarlett@newcastle.edu.au \\ 2 Department of Food Technology, Faculty of Food Technology, Nha Trang University, No. 2 Nguyen Dinh \\ Chieu, Nha Trang 8458, Vietnam \\ 3 Department of Medical Oncology, Calvary Mater Newcastle Hospital, Waratah, NSW 2298, Australia; \\ Jennette.Sakoff@newcastle.edu.au \\ * Correspondence: vantang.nguyen@uon.edu.au or tangnv@ntu.edu.vn; Tel.: +61-434-238-842
}

Received: 11 May 2017; Accepted: 15 June 2017; Published: 18 June 2017

\begin{abstract}
Background: Phyllanthus amarus (P. amarus) has been used as a medicinal plant for the prevention and treatment of chronic ailments such as diabetes, hepatitis, and cancer. Methods: The physicochemical properties, antioxidant and cytotoxic activities of crude extracts and fractions from P. amarus were determined using spectrophotometric method. Results: The P. amarus methanol (PAM) extract had lower levels of residual moisture $(7.40 \%)$ and water activity $(0.24)$ and higher contents of saponins, phenolics, flavonoids, and proanthocyanidins (1657.86 mg escin equivalents, $250.45 \mathrm{mg}$ gallic acid equivalents, $274.73 \mathrm{mg}$ rutin equivalents and $61.22 \mathrm{mg}$ catechin equivalents per $\mathrm{g}$ dried extract, respectively) than those of the P. amarus water ( $P A W)$ extract. The antioxidant activity of PAM extract was significantly higher $(p<0.05)$ than that of the PAW extract, PAM fractions, and phyllanthin (known as a major compound in the P. amarus). Higher cytotoxic activity of PAM extract based on MTT assay on different cell lines including MiaPaCa-2 (pancreas), HT29 (colon), A2780 (ovarian), H460 (lung), A431 (skin), Du145 (prostate), BE2-C (neuroblastoma), MCF-7 (breast), MCF-10A (normal breast), and U87, SJ-G2, SMA (glioblastoma) was observed in comparison to the PAW extract and PAM fractions. The cytotoxic potential of the PAW extract $(200 \mu \mathrm{g} / \mathrm{mL})$, based on the CCK-8 assay on a pancreatic cancer cell line $(\mathrm{MiaCaPa} 2)$ was significantly lower $(p<0.05)$ than those of gemcitabine $(50 \mathrm{nM})$ and a saponin-enriched extract from quillajia bark at $200 \mu \mathrm{g} / \mathrm{mL}$ (a commercial product), but was significantly higher than that of phyllanthin at $2 \mu \mathrm{g} / \mathrm{mL}$. Conclusions: The results achieved from this study reveal that the $P A$ extracts are a potential source for the development of natural antioxidant products and/or novel anticancer drugs.
\end{abstract}

Keywords: Phyllanthus amarus; extracts; fractions; physicochemical; antioxidant; cytotoxicity

\section{Introduction}

Cancer is a leading cause of death worldwide, accounting for 8.2 million deaths in 2012, in which pancreatic cancer (PC) is the fourth leading cause of cancer deaths in Western societies, with an overall 5 -year survival of less than $7 \%$, and the figures have not changed for several decades [1-4]. Although much research in PC treatment has been performed in recent years, PC is still a therapeutic challenge. Currently, the pancreatectomy is the only cure for PC in the early stages. Other treatment methods such as chemo, targeted, and radiotherapies are also utilized in later stages of PC. In regards to chemotherapy, current chemotherapeutic agents such as gemcitabine (a purine analog), fluoropyrimidine, and/or platinum drugs have been used. Further, erlotinib is an epidermal growth factor receptor tyrosine 
kinase inhibitor, which is used as a supplement to gemcitabine [1]. Pyrrolidine dithiocarbamate or disulfiram synergistically inhibited PC cell proliferation when used in combination with gemcitabine and enhancement by zinc ions [5]. A four-drug combination, named FOLFIRINOX (oxaliplatin, irinotecan, flurouracil, and leucovorin) demonstrated superiority in PC treatment with a median overall survival of 11 months, while median overall survival of 2, 6, 6-7, and 8.5 months for PC treatment with no therapy, gemcitabine alone, gemcitabine plus capecitabine or erlotinib, and gemcitabine plus abraxane or nab-paclitaxel, respectively $[2,6]$. However, the major challenge of these anticancer drugs is that they are highly toxic with limited treatment results, and are associated with degradation in the quality of life.

Over the past 30 years, about $45 \%$ of all anticancer drugs have been derived directly or indirectly from plant compounds, of which $12 \%$ are natural products and $32 \%$ are semi-synthetic derivatives of natural related products, with a number of plant-sourced agents in currently clinical use for the treatment of various cancers, such as taxanes from the Taxus brevifolia tree, vinca alkaloids from the Catharanthus roseus leaves, camptothecin analogs from the Camptotheca acuminata tree, and podophyllotoxin analogs from the Podophyllum peltatum plants [7]. Some plant-derived anticancer agents have been used for the treatment of pancreatic cancer, such as irinotecan, docetaxel, paclitaxel, triptolide, and minnelide (semi-synthetic) [8,9]. The traditional use of plants as folk medicine for cancer prevention and treatment in China, Ayurveda, Greco-Arabic traditions, European, Anthrosophical medicine, and North American traditions is also reported [10]. Therefore, the use of herbal medicines for cancer prevention and treatment is of great interest to researchers and patients because of lower toxicity and high availability [3].

Phyllanthus amarus (P. amarus) is broadly distributed in tropical and subtropical areas and used as a traditional herbal plant. Previous studies showed that the $P$. amarus extract contains a wide range of bioactive compounds, such as polyphenols, flavonoids, proanthocyanidins, triterpenes, saponins, lignans (phyllanthin), ellagitannins, sterols, and alkaloids [11,12], which display potent pharmacological activities, particularly anti-hepatitis [13,14], antioxidant [15-17], and anticancer activities [18-21].

Up to now, the physicochemical and biological properties of P. amarus (PA) extracts and fractions have not been sufficiently reported. For example, the antioxidant capacity of $P A$ was determined for dried samples and extracts using assay of free radical scavenging capacity $[17,21]$, but not for fractions from $P A$ extract, while cytotoxic activity of $P A$ extracts has been evaluated on several human cancer cell lines (colon: Caco-2 [18], lung: A549 and breast: MCF-7 [19,20], and hepatoma: HepG2 [21]) using 3-(4,5-dimethylthiazol-2-yl)-2,5-diphenyltetrazolium bromide (MTT) assay, but not focused on pancreatic cancer cell lines. With this in mind, our current study aimed to determine the physicochemical properties as well as to evaluate the antioxidant and cytotoxic activities of crude extracts and fractions from $P A$ extract. Antioxidant analysis involved assays of free radical scavenging capacity and ferric reducing antioxidant power, while cytotoxic evaluation involved MTT assays and a Dojindo cell counting kit-8 (CCK-8), both targeting pancreatic cancer cell lines, to evaluate the potential application of $P A$ extracts in the nutraceutical, medical, pharmaceutical, and cosmetic industries.

\section{Materials and Methods}

\subsection{Plant Material}

The whole plant of Phyllanthus amarus was collected in January 2015 from Hon Nghe, Vinh Ngoc, Nha Trang city, Khanh Hoa province, Vietnam and authenticated by Quang Ngai Union of the Science and Technology Association, Vietnam. Briefly, the fresh samples were placed in sealed plastic bags, covered with ice to minimize oxidation, and rapidly taken to the laboratories at the Nha Trang University. The fresh samples were then rinsed in deionized water to remove sand, soil, and foreign materials, drained, and dried by infrared exposure at $30^{\circ} \mathrm{C}$ to constant weight in an infrared drying cabinet (SHN-L, Nha Trang University, Vietnam [15]) packaged in the vacuum sealed polyamide bags, 
and stored at $-20{ }^{\circ} \mathrm{C}$ until required. Residual moisture of dried P. amarus sample was analyzed based on the Association of Official Analytical Chemists (AOAC) official methods of analysis [22] in a hot-air oven (Anax Pty Ltd., Sydney, NSW, Australia) at $120^{\circ} \mathrm{C}$ to constant weight.

\subsection{Analytical Chemicals}

In this study, all chemicals were of analytical grade. Folin-Ciocalteu reagent, 2,2'-Azino-bis(3-ethylbenzothiazoline-6- sulphonic acid) (ABTS), 2,2-diphenyl-1-picryl-hydrazil (DPPH), gallic acid, rutin, catechin, ostruthin, gemcitabine, trolox, neocuproine, 2,4,6-tripyridyls-triazine (TPTZ), saponin-enriched quillaja bark extract, and iron (III) chloride were products of Sigma-Aldrich Pty Ltd. (Castle Hill, Sydney, NSW, Australia). Sulfuric acid and hydrochloric acid were purchased from Ajax Finechemicals (Sydney, NSW, Australia). Acetic acid was obtained from BDH Laboratory Supplies (Poole, England). Vanillin, potassium persulfate, sodium nitrite, methanol, and acetonitrile were purchased from Merck (Darmstadt, Germany). Sodium acetate trihydrate was obtained from Government Stores Department (Sydney, NSW, Australia). Ammonium acetate was purchased from BDH Chemicals (Boronia, VIC, Australia). Copper (II) chloride was obtained from Standard Laboratories (Maribyrnong, VIC, Australia). Aluminium chloride was purchased from Acros (Morris Plains, NJ, USA). Sodium carbonate anhydrous was obtained from Chem-supply (Adelaide, South Australia, Australia). Sodium hydroxide was purchased from Ajax chemicals (Sydney, NSW, Australia). 3-(4,5-dimethylthiazol-2-yl)-2,5-diphenyltetrazolium bromide (MTT), Dulbecco's Modified Eagle's Medium (DMEM) and Keratinocyte Serum-Free Medium (KSFM) were products of Gibco by Life Technologies (Grand Island, NY, USA). Dojindo Cell Counting Kit-8 (CCK-8) was obtained from Dojindo Molecular Technologies, Inc. (Rockville, MD, USA).

\subsection{Preparation of Powdered P. amarus Extracts}

PA extracts were prepared according to the previously described methods [17,23]. Briefly, $10 \mathrm{~g}$ of dried sample was soaked in $1000 \mathrm{~mL}$ of deionized water (for water extract) or $100 \%$ methanol (for methanol extract) at room temperature $\left(21 \pm 1^{\circ} \mathrm{C}\right.$ ) for $20 \mathrm{~min}$, followed by microwave-assisted extraction in a microwave oven (Sharp Carousel, Sharp Corporation, Bangkok, Thailand) at a power of $600 \mathrm{~W}$, an irradiation time of $4 \mathrm{~s} / \mathrm{min}$ and an extraction time of $50 \mathrm{~min}$ for water extract, or a power of $360 \mathrm{~W}$, an irradiation time of $7 \mathrm{~s} / 2 \mathrm{~min}$ and an extraction time of $40 \mathrm{~min}$ for methanol extract. After that, the extracts were rapidly cooled to room temperature in an ice water bath and filtered through qualitative No. 1 filter papers (Bacto Laboratories Pty Ltd., Mount Pritchard, NSW, Australia). The extracts were then evaporated under reduced pressure $(-10 \mathrm{mbar})$ at $40{ }^{\circ} \mathrm{C}$ using a rotavapor (Buchi, Flawil, Switzerland) and dried to constant weight in a freeze drier (Rietschle Thomas Australia Pty Ltd., Seven Hills, NSW, Australia) at $-45^{\circ} \mathrm{C}, 0.1 \mathrm{~atm}$ for $48 \mathrm{~h}$ to obtain the powdered PA extracts, and stored at $-20^{\circ} \mathrm{C}$ until required. For the antioxidant capacity determination of the $P A$ extracts, the powdered $P A$ extracts were redissolved in $100 \%$ methanol at a concentration of $200 \mu \mathrm{g} / \mathrm{mL}$ using a fine vortex mixer (FINEPCR, Gyeonggi-do, Korea) until the solutions became completely clear and no little particles in suspension was observed.

\subsection{Determination of Physicochemical Properties of Powdered P. amarus Extracts}

\subsubsection{Residual Moisture and Water Activity}

The residual moisture of the $P A$ extracts was analyzed based on the AOAC official methods of analysis [22] at $100{ }^{\circ} \mathrm{C}$ to constant weight in a hot-air oven (Anax Pty Ltd., Sydney, NSW, Australia). Water activity $\left(\mathrm{a}_{\mathrm{w}}\right)$ of $P A$ extracts was measured at room temperature using a water activity meter ( $\mathrm{Pa}_{\mathrm{w}}$ kit, Decagon Devices, Washington, DC, USA). 


\subsubsection{Total Phenolic Content (TPC)}

The TPC of the PA extracts was quantified based on the previous study [24] with some modifications. To $0.5 \mathrm{~mL}$ of the extract was mixed with $2.5 \mathrm{~mL}$ of $10 \%(v / v)$ Folin-Ciocalteu reagent in distilled water. The mixture was kept for $6 \mathrm{~min}$, then $2 \mathrm{~mL}$ of $7.5 \%(w / v) \mathrm{Na}_{2} \mathrm{CO}_{3}$ solution was added. The absorbance of the mixture was measured at $765 \mathrm{~nm}$ using a UV-VIS spectrophotometer (Cary 50 Bio, Mulgrave, VIC, Australia) after incubation in the dark at room temperature for $1 \mathrm{~h}$. Methanol was used as a control. TPC was quantified as $\mathrm{mg}$ gallic acid equivalents (GAE)/g dried extract.

\subsubsection{Total Flavonoid Content (TFC)}

The TFC of the PA extracts was analyzed using the formerly reported method [24]. $0.5 \mathrm{~mL}$ of the extract was mixed with $2 \mathrm{~mL}$ of distilled water and $0.15 \mathrm{~mL}$ of $5 \%(w / v) \mathrm{NaNO}_{2}$ solution. The mixture was then kept in the dark at room temperature for $6 \mathrm{~min}$. After that, $0.15 \mathrm{~mL}$ of $10 \%(w / v)$ $\mathrm{AlCl}_{3}$ solution was added and the mixture was kept for $6 \mathrm{~min}$. Finally, $2 \mathrm{~mL}$ of $4 \%(w / v) \mathrm{NaOH}$ solution and $0.7 \mathrm{~mL}$ of distilled water were added and the mixture was incubated for $15 \mathrm{~min}$. The absorbance of mixture was measured at $510 \mathrm{~nm}$. Methanol and rutin were used as a control and standard, respectively. TFC was calculated as $\mathrm{mg}$ of rutin equivalents (RE)/g dried extract.

\subsubsection{Proanthocyanidin Content}

The proanthocyanidin content of the $P A$ extracts was estimated based on the previously presented method [24]. To $0.5 \mathrm{~mL}$ of the extract was mixed with $3 \mathrm{~mL}$ of $4 \%(w / v)$ vanillin solution and $1.5 \mathrm{~mL}$ of concentrated $\mathrm{HCl}$. The mixture was kept in the dark at room temperature for 15 min before measuring absorbance at $500 \mathrm{~nm}$. Methanol and catechin were used as a control and standard, respectively. Proanthocyanidin content was estimated as $\mathrm{mg}$ of catechin equivalents (CE)/g dried extract.

\subsubsection{Saponin Content (SC)}

The saponin content (include several sapogenins like sterols and steroids) of the PA extracts was determined according to the prior work [17]. To $0.5 \mathrm{~mL}$ of the extract was mixed with $0.5 \mathrm{~mL}$ of $8 \%$ $(w / v)$ vanillin solution and $5 \mathrm{~mL}$ of $72 \%(v / v) \mathrm{H}_{2} \mathrm{SO}_{4}$ solution. The mixture was kept at $70{ }^{\circ} \mathrm{C}$ for 15 min and then rapidly cooled by an ice water bath to room temperature. The absorbance of the mixture was measured at $560 \mathrm{~nm}$. Methanol was used as a control. Saponin content was quantified as mg of escin equivalents (EE)/g dried extract.

\subsubsection{Isolation of Major Fractions from P. amarus Methanol (PAM) Extract}

Based on the results of physicochemical analysis above, we selected the PAM extract for the separation of major fractions for further evaluation of their antioxidant and cytotoxic activities. A Shimadzu HPLC system (Shimadzu, Chiyoda-ku, Tokyo, Japan was used for isolation of major fractions from the PAM extract based on the previously established method [25]. Basically, the original PAM extract after filtering through qualitative filter paper and evaporating under reduce pressure was filtered through $0.45 \mu \mathrm{m}$ nylon membranes (Phenex syringe filters) and then $300 \mu \mathrm{L}$ of the extract was injected by an auto sampler (SIL-10AV, Shimadzu, Kyoto, Japan) onto a Semi-prep Phenomenex Synergy 4U Polar-RP 80A column $(250 \mathrm{~mm} \times 10 \mathrm{~mm}$ ) (Phenomenex, Torrance, CA, USA). The column was kept at $35^{\circ} \mathrm{C}$ in an oven thermal sphere (Phenomenex, Torrance, CA, USA) and coupled to an auto fraction collector (FRC-10A, Shimadzu, Kyoto, Japan). The mobile phase included two solvents: $0.2 \%$ orthophosphoric acid in distilled water (A) and 100\% acetonitrile (B). The flow rate was $3 \mathrm{~mL} / \mathrm{min}$ with the gradient as follows: 0-5 min, 0\% B; 5-20 min, 20\% B; 20-30 min, 30\% B; 30-48 min, 30\% B; 48-53 min, 0\% B. Bioactive compounds were detected at $210 \mathrm{~nm}$ using a diode array detector (8PD-M20A, Shimadzu, Kyoto, Japan). Isolation of major fractions from the PAM extract was achieved based on retention time of these compounds. Nine major fractions were separately collected from the fraction collector (284 runs in total). These fractions were then evaporated under reduced pressure 
(-30-50 mbar) at $45-60{ }^{\circ} \mathrm{C}$ using a rotavapor (Buchi, Flawil, Switzerland), dried to a constant weight in a freeze drier (Rietschle Thomas Australia Pty Ltd., Seven Hills, NSW, Australia) at $-45^{\circ} \mathrm{C}, 0.1 \mathrm{~atm}$ for $72 \mathrm{~h}$ to obtain the powdered PAM factions, and stored them at $-20{ }^{\circ} \mathrm{C}$ until used for further assessment.

\subsection{Determination of Antioxidant Capacity of Powdered P. amarus Extracts and Fractions}

\subsubsection{ABTS Radical Scavenging Capacity (ARSC)}

The ARSC of the PA extracts and fractions was evaluated using the formerly established method [26] with some modifications. Briefly, a stock solution was prepared by mixing $7.4 \mathrm{mM}$ $\mathrm{ABTS}^{\bullet+}$ and $2.6 \mathrm{mM} \mathrm{K}_{2} \mathrm{~S}_{2} \mathrm{O}_{8}$ solutions (1:1 ratio), kept in the dark at room temperature for $12 \mathrm{~h}$, and stored at $-20{ }^{\circ} \mathrm{C}$. Prior to use, mixing $1 \mathrm{~mL}$ of stock solution with $60 \mathrm{~mL}$ of methanol was performed to obtain a working solution with absorbance of $1.1 \pm 0.02$ at $734 \mathrm{~nm} .0 .15 \mathrm{~mL}$ of the extract was mixed with $2.85 \mathrm{~mL}$ of the working solution and incubated in the dark at room temperature for $2 \mathrm{~h}$. The absorbance of mixture was measured at $734 \mathrm{~nm}$. Methanol and ostruthin were used as a control and positive control, respectively. The results were calculated as $\mathrm{mg}$ trolox equivalents (TE)/g dried sample.

\subsubsection{DPPH Radical Scavenging Capacity (DRSC)}

The DRSC of the PA extracts and fractions was measured based on the previous study [24] with some modifications. Briefly, $0.024 \%(w / v)$ DPPH in methanol was prepared to make a stock solution and stored at $-20^{\circ} \mathrm{C}$. Before use, $1.0 \mathrm{~mL}$ of stock solution was diluted with $45 \mathrm{~mL}$ of methanol to obtain a working solution with absorbance of $1.1 \pm 0.02$ at $515 \mathrm{~nm} .0 .15 \mathrm{~mL}$ of the extract was mixed with $2.850 \mathrm{~mL}$ of the working solution and incubated in the dark at room temperature for $3 \mathrm{~h}$. The absorbance of mixture was measured at $515 \mathrm{~nm}$. Methanol and ostruthin were used as a control and positive control, respectively. The results were estimated as $\mathrm{mg}$ trolox equivalents (TE)/g dried sample.

\subsubsection{Ferric Reducing Antioxidant Power (FRAP)}

The FRAP of the PA extracts and fractions was estimated based on the former report [27] with some modifications. Three regents were prepared including $300 \mathrm{mM}$ acetate buffer solution at $\mathrm{pH} 3.6$ (reagent A); $10 \mathrm{mM} \mathrm{TPTZ} \mathrm{solution} \mathrm{in} 40 \mathrm{mM} \mathrm{HCl}$ (reagent B); and $20 \mathrm{mM} \mathrm{FeCl}_{3} \cdot 6 \mathrm{H}_{2} \mathrm{O}$ solution (reagent C). Prior to use, reagents A, B, and C were mixed at a ratio of 10:1:1 to make a fresh FRAP solution. $0.15 \mathrm{~mL}$ of the extract was mixed with $2.850 \mathrm{~mL}$ of the fresh FRAP solution and incubated in the dark at room temperature for $30 \mathrm{~min}$. The absorbance of mixture was read at $593 \mathrm{~nm}$. Methanol and ostruthin were used as a control and positive control, respectively. The results were calculated as mg trolox equivalents (TE)/g dried sample.

\subsection{Assessment of Cytotoxic Potential of Powdered P. amarus Extracts and Fractions}

\subsubsection{Growth Inhibition of Cancer Cell Lines by PA Extracts}

The cytotoxic potential of $P A$ extracts was assessed according to a previously reported methods [4,28] based on the growth inhibition of $P A$ extracts on eleven cancer cell lines including MiaPaCa-2 (pancreas), HT29 (colon), A2780 (ovarian), H460 (lung), A431 (skin), Du145 (prostate), BE2-C (neuroblastoma), MCF-7 (breast), and U87, SJ-G2, SMA (glioblastoma) and one non-cancer derived cell line MCF-10A (normal breast). Briefly, all cancer cell lines were cultured in DMEM supplemented with $10 \%$ fetal bovine serum, $50 \mathrm{IU} / \mathrm{mL}$ penicillin, $50 \mu \mathrm{g} / \mathrm{mL}$ streptomycin, and 2 mM L-glutamine. The MCF-10A cells were cultured in DMEM:F12 (1:1) cell culture media, 5\% heat inactivated horse serum, supplemented with $50 \mathrm{IU} / \mathrm{mL}$ penicillin, $50 \mu \mathrm{g} / \mathrm{mL}$ streptomycin, $20 \mathrm{mM}$ Hepes, $2 \mathrm{mM}$ L-glutamine, $20 \mathrm{ng} / \mathrm{mL}$ epidermal growth factor, $500 \mathrm{ng} / \mathrm{mL}$ hydrocortisone, $100 \mathrm{ng} / \mathrm{mL}$ cholera toxin, and $10 \mu \mathrm{g} / \mathrm{mL}$ insulin. Cells were plated in triplicate in $100 \mu \mathrm{L}$ DMEM on a 96-well plate, at a density of 2500-4000 cells per well. When cells were at logarithmic growth after $24 \mathrm{~h}$, medium 
without (control) and with the $P A$ extracts $(100 \mu \mathrm{L})$ was added to each well to give a final concentration of $100 \mu \mathrm{g} / \mathrm{mL}$ (day 0). MTT assay was employed where absorbance was read at $540 \mathrm{~nm}$ to determine growth inhibition after $72 \mathrm{~h}$ of incubation based on the difference between the optical density values on day 0 and those at the end of drug exposure. Cell growth inhibition as a percentage was determined where a value of $100 \%$ is indicative of total growth inhibition, while a value greater than $100 \%$ is indicative of growth inhibition and cell death.

2.6.2. Viability of Pancreatic Cancer and Normal Cells by Treatment with P. amarus Methanol (PAM) Extract and Fractions

\section{Cell Culture}

A human pancreatic cancer cell line $\left(\mathrm{MiaPaCa}_{2}\right)$ and a normal human pancreatic ductal epithelial (HPDE) cell line were cultured based on the previously described methods [3,4] with some modifications. Briefly, the cells were grown in DMEM supplemented with $10 \%$ fetal bovine serum (FBS), 2.5\% horse serum, and 1\% L-glutamine for $\mathrm{MiaPaCa}_{2}$ or KSFM supplemented with $2.5 \mu \mathrm{g}$ epidermal growth factor (EGF) human recombinant and $25 \mathrm{mg}$ bovine pituitary extract (BPE) for $\mathrm{HPDE}$ at $37^{\circ} \mathrm{C}$ with $5 \% \mathrm{CO}_{2}$, respectively.

\section{Cell Viability}

Cell viability was determined using the CCK- 8 assay based on the formerly reported methods $[3,4]$ with some modifications. Briefly, cells were seeded into a 96 well plate at $3 \times 10^{3}$ cells per well for $\mathrm{MiaPaCa}_{2}$ or $7 \times 10^{3}$ cells per well for HPDE and allowed to adhere for $24 \mathrm{~h}$ at $37^{\circ} \mathrm{C}$ with $5 \% \mathrm{CO}_{2}$. Media was removed and the cells were then treated with various concentrations of the PAM extract in the media $(200-12.5 \mu \mathrm{g} / \mathrm{mL})$, its fractions $(50 \mu \mathrm{g} / \mathrm{mL})$, ostruthin $(20 \mu \mathrm{g} / \mathrm{mL})$, and gemcitabine $(50 \mathrm{nM})$ as positive controls, quillaja bark extract $(200 \mu \mathrm{g} / \mathrm{mL})$ as a comparative sample, and $0.5 \%$ DMSO as a control. After $72 \mathrm{~h}$ incubation at $37{ }^{\circ} \mathrm{C}$ with $5 \% \mathrm{CO}_{2}$, the media was removed and $100 \mu \mathrm{L}$ of $10 \%$ CCK-8 solution in the media was added and incubated at $37^{\circ} \mathrm{C}$ with $5 \% \mathrm{CO}_{2}$ for $2 \mathrm{~h}$. Absorbance was measured at $450 \mathrm{~nm}$ and cell viability was expressed as a percentage of control.

\subsection{Statistical Analysis}

All experiments were carried out at least in triplicate. The results were analyzed using SPSS software (Version 22, SPSS Inc., Chicago, IL, USA) and expressed as means \pm standard deviations. Statistical comparisons were made using one-way analysis of variance (ANOVA) and Tukey HSD post hoc tests. $p$-values at least 0.05 were considered to be significantly different.

\section{Results and Discussion}

\subsection{Physicochemical Properties of Powdered P. amarus Extracts}

Residual moisture and water activity of powdered extracts affect greatly their stability and storability. Table 1 shows that residual moisture and water activity of the powdered $P A$ extracts ranged from 7.40 to $8.85 \%$ and 0.24 to 0.35 , respectively, revealing that the freeze drying method used in this study was a suitable method for preparing the powdered $P A$ extracts. The residual moisture of the powdered $P A$ extracts obtained in this study was lower than that of saponin-enriched bitter melon powder $(9.2-12.1 \%)$, while its water activity was comparable to that of bitter melon powder (0.2-0.4) [29]. Chirife and Fontana [30] reported that water activity in the range from 0.45 to 0.68 can inhibit the proliferation of microorganisms and enzyme activity, leading to increase storability of samples. Table 1 also shows that the PAM extract was richer in saponins, phenolics, flavonoids, and proanthocyanidins (1657.86 mg escin equivalents, $250.45 \mathrm{mg}$ gallic acid equivalents, $274.73 \mathrm{mg}$ rutin equivalents, and $61.22 \mathrm{mg}$ catechin equivalents/g dried extract, respectively) than those of the PAW extract (1037.34 mg escin equivalents, $86.89 \mathrm{mg}$ gallic acid equivalents, $158.17 \mathrm{mg}$ rutin equivalents, 
and $37.05 \mathrm{mg}$ catechin equivalents/g dried extract, respectively), which were much higher than those of bitter melon powder (77.1-113.6 mg escin equivalents, 17.0-22.4 mg gallic acid equivalents, 2.8-5.8 $\mathrm{mg}$ rutin equivalents, and 1.9-3.2 mg catechin equivalents/g dried powder, respectively) [29]. Previous studies reported that phenolics display potent antioxidant activity [16,31], while saponins possess great anticancer capacity [32,33]. The results from this study have given a hypothesis that the PA extracts may be a potential source against oxidation and cancer, which are assessed and presented in the next sections.

Table 1. Physicochemical properties of powdered P. amarus water and methanol extracts.

\begin{tabular}{ccc}
\hline Properties & Water Extract & Methanol Extract \\
\hline Residual moisture (\%) & $8.85 \pm 0.74 *$ & $7.40 \pm 0.14$ \\
Water activity (aw) & $0.35 \pm 0.02$ & $0.24 \pm 0.02$ \\
Total phenolic content (mg GAE/g dried extract) & $86.89 \pm 6.06$ & $250.45 \pm 11.93$ \\
Total flavonoid content (mg RE/g dried extract) & $158.17 \pm 14.38$ & $274.73 \pm 1.56$ \\
Proanthocyanidin content (mg CE/g dried extract) & $37.05 \pm 6.03$ & $61.22 \pm 13.94$ \\
Saponin content (mg EE/g dried extract) & $1037.34 \pm 52.17$ & $1657.86 \pm 441.62$ \\
\hline
\end{tabular}

* Means and standard deviations were of triplicate. GAE: Gallic acid equivalents; RE: Rutin equivalents; CE:

Catechin equivalents; EE: Escin equivalents.

\subsection{Major Fractions Isolated from P. amarus Methanol (PAM) Extract}

Figure 1 shows the HPLC chromatogram of the PAM extract detected at $210 \mathrm{~nm}$. Based on the retention time of bioactive compounds, nine major fractions, numbered F1 to F9, were isolated from the PAM extract and collected using an auto fraction collector. These included: F1: 4.72-5.40 min, F2: 6.65-7.11 min, F3: 10.10-11.20 min, F4: 18.40-19.35 min, F5: 28.40-28.85 min, F6: 29.02-29.60 min, F7: 30.00-30.50 min, F8: 31.75-32.34 min, and F9: 32.90-33.30 min. The dried weight of the powdered PAM fractions after freeze drying were obtained as follows: F1: $1.093 \mathrm{~g}$, F2: $0.925 \mathrm{~g}$, F3: $1.507 \mathrm{~g}, \mathrm{~F} 4$ : $1.401 \mathrm{~g}$, F5: $0.858 \mathrm{~g}$, F6: $0.801 \mathrm{~g}$, F7: $0.695 \mathrm{~g}$, F8: $1.059 \mathrm{~g}$, and F9: $0.534 \mathrm{~g}$, which were then used for the assessment of antioxidant and cytotoxic activities. However, the PAM fractions have not yet been identified in this study, therefore further study may be required to characterize these PAM fractions and purify them for further applications. Nguyen at al. [4] also used a HPLC system coupled to an auto fraction collector to isolate completely four major fractions from $P$. trimera root methanol extract for assessing their antioxidant and cytotoxic capacities.

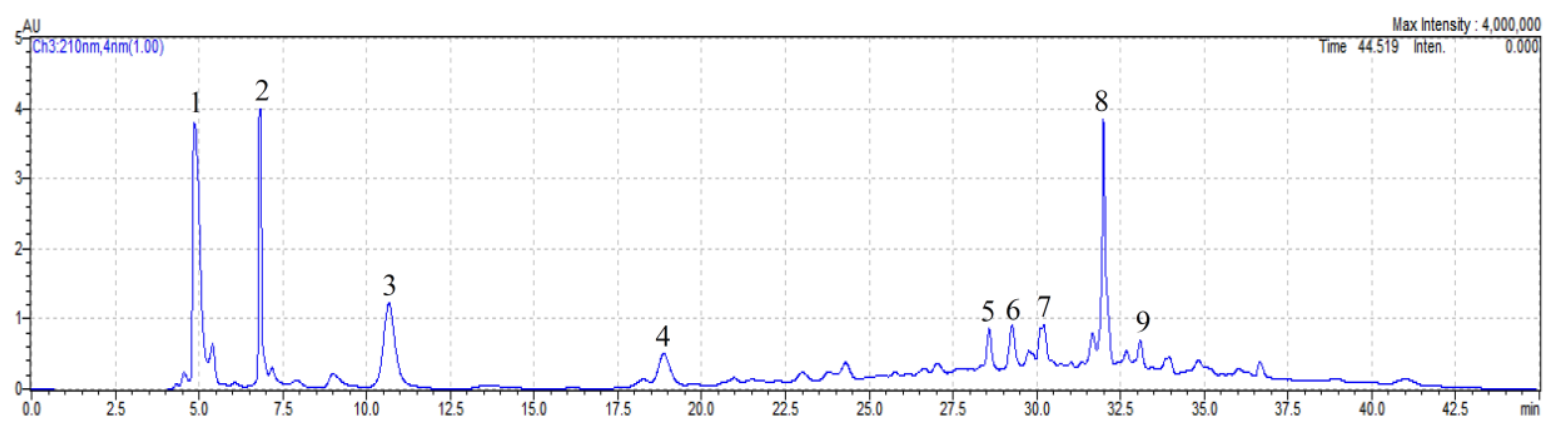

Figure 1. HPLC chromatogram of P. amarus methanol (PAM) extract with PDA detector set at $210 \mathrm{~nm}$.

\subsection{Antioxidant Capacity of Powdered P. amarus Extracts and Fractions}

Figure 2 shows ABTS radical scavenging capacity (ARSC) of $P A$ extracts, nine fractions from the PAM extract and phyllanthin. At $200 \mu \mathrm{g} / \mathrm{mL}$, the ARSC of the PAW extract $(962.20 \mathrm{mg}$ TE/g dried sample) was significantly higher $(p<0.05)$ than those of the PAM extract, phyllanthin, and all nine PAM fractions $(827.74,62.89$, and $2.62-8.75 \mathrm{mg} \mathrm{TE} / \mathrm{g}$ dried sample, respectively), indicating that phyllanthin and the PAM fractions displayed weak antioxidant capacity when compared to $P A$ extracts. 
Potent ARSC of both PA extracts was likely contributed by high contents of phenolics, flavonoids, and proanthocyanidins (86.89 mg GAE, $158.17 \mathrm{mg}$ RE and $37.05 \mathrm{mg}$ CE/g dried extract for PAW extract; and $250.45 \mathrm{mg} \mathrm{GAE}, 274.73 \mathrm{mg}$ RE and $61.22 \mathrm{mg} \mathrm{CE} / \mathrm{g}$ dried extract for PAM extract, respectively) [16].

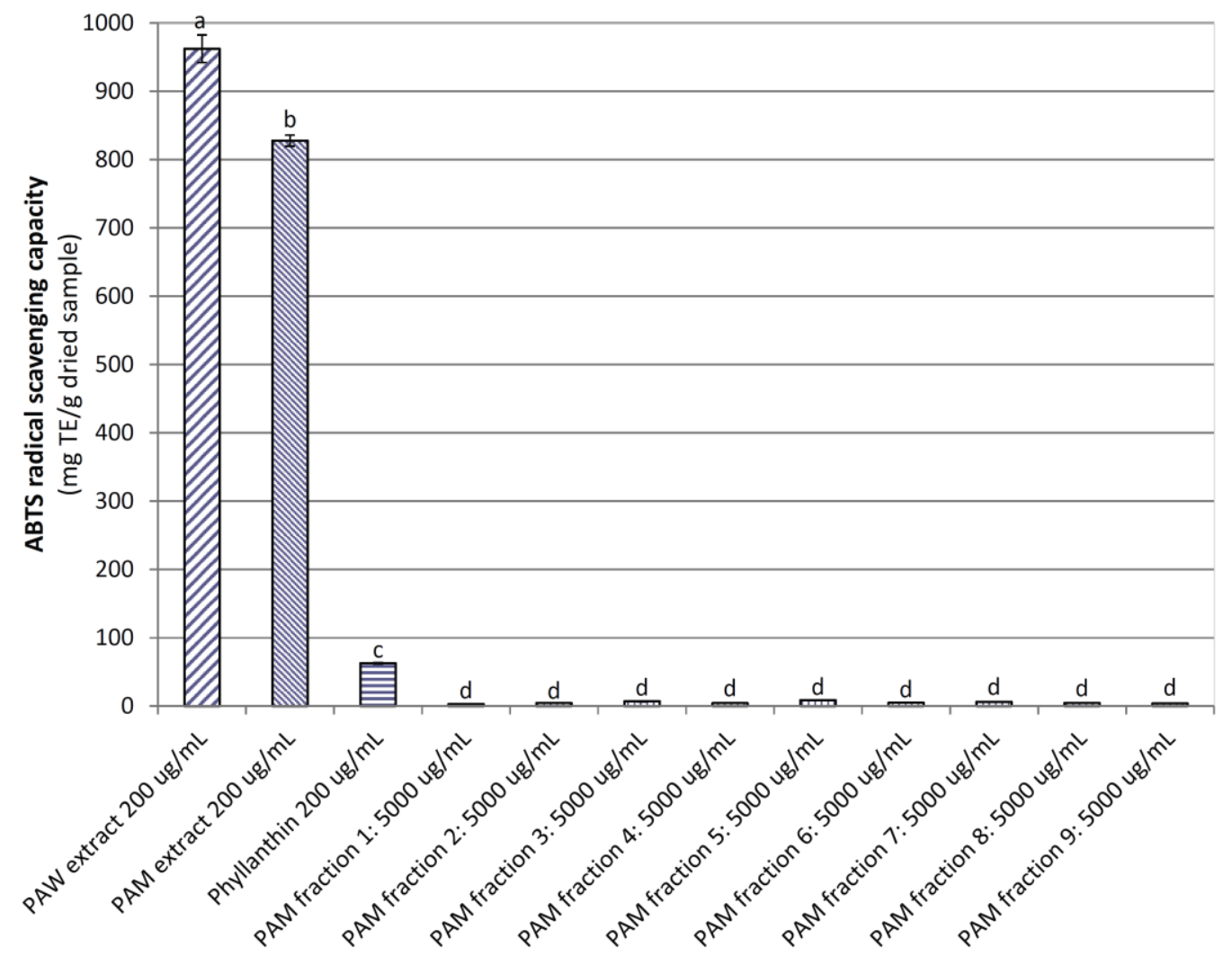

Figure 2. ABTS radical scavenging capacity of powdered P. amarus water (PAW) and methanol (PAM) extracts and PAM fractions. Phyllanthin was used as a positive control. Different letters within the columns denotes a significant difference between treatments $(p<0.05)$.

In contrast, the DPPH radical scavenging capacity (DRSC) of the PAM extract (440.13 mg TE/g dried sample) was significantly higher $(p<0.05)$ than those of the PAW extract, phyllanthin, and the nine PAM fractions (319.14, 25.62, and 1.89-4.68 $\mathrm{mg}$ TE/g dried sample, respectively; Figure 3). The higher contents of phenolics, flavonoids, and proanthocyanidins in the PAM extract mainly contributed to its stronger DRSC when compared to the PAW extract [34]. Previous studies have also indicated a positive correlation between phenolics, flavonoids, and proanthocyanidins and the DRSC of P. trimera root [35] and P. amarus [16]. The study [36] showed the P. amarus extract and phyllanthin concentrations for maximum DRSC were $300 \mu \mathrm{g} / \mathrm{mL}$ and $20 \mu \mathrm{mol} / \mathrm{mL}$, with the $\mathrm{IC}_{50}$ being $162.3 \mu \mathrm{g} / \mathrm{mL}$ versus $7.4 \mu \mathrm{mol} / \mathrm{mL}$.

Similar to the DRSC, the ferric reducing antioxidant power (FRAP) of the PAW extract, phyllanthin, and nine PAM fractions (320.39, 44.57, and 2.14-3.83 mg TE/g dried sample) was significantly lower $(p<0.05)$ than that of the PAM extract $(380.22 \mathrm{mg} \mathrm{TE} / \mathrm{g}$ dried sample; Figure 4). Strong FRAP of both $P A$ extracts would have also been as a consequence of their high phenolic, flavonoid, and proanthocyanidin contents. This outcome is supported by previous studies, which reported that the FRAP of the extracts had a positive correlation with their TPC, for example, E. robusta leaf [28], E. tirucalli [37], and P. amarus [16]. 


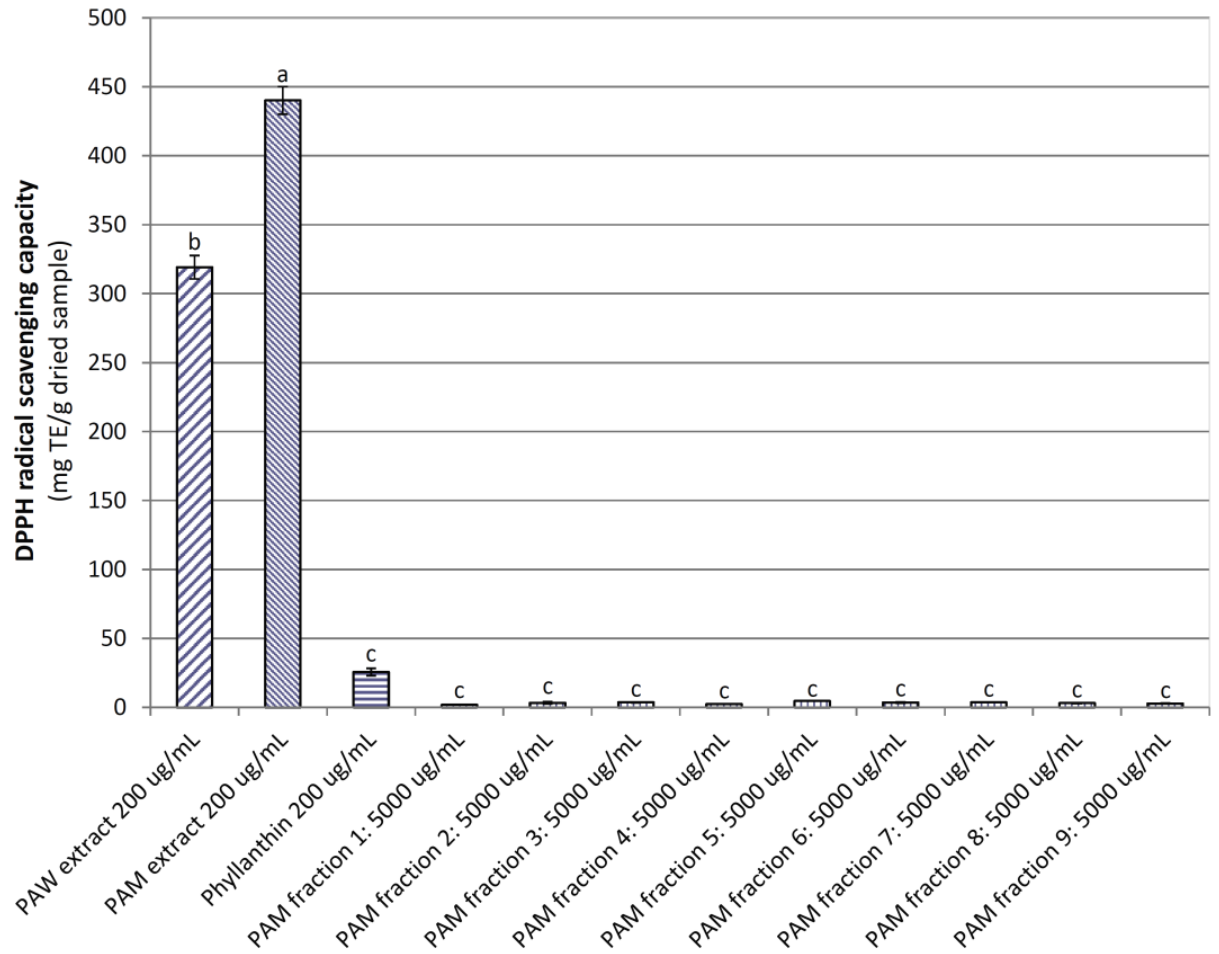

Figure 3. The DPPH radical scavenging capacity of powdered P. amarus water (PAW) and methanol (PAM) extracts and PAM fractions. Phyllanthin was used as a positive control. Different letters within the columns denotes a significant difference between treatments $(p<0.05)$.

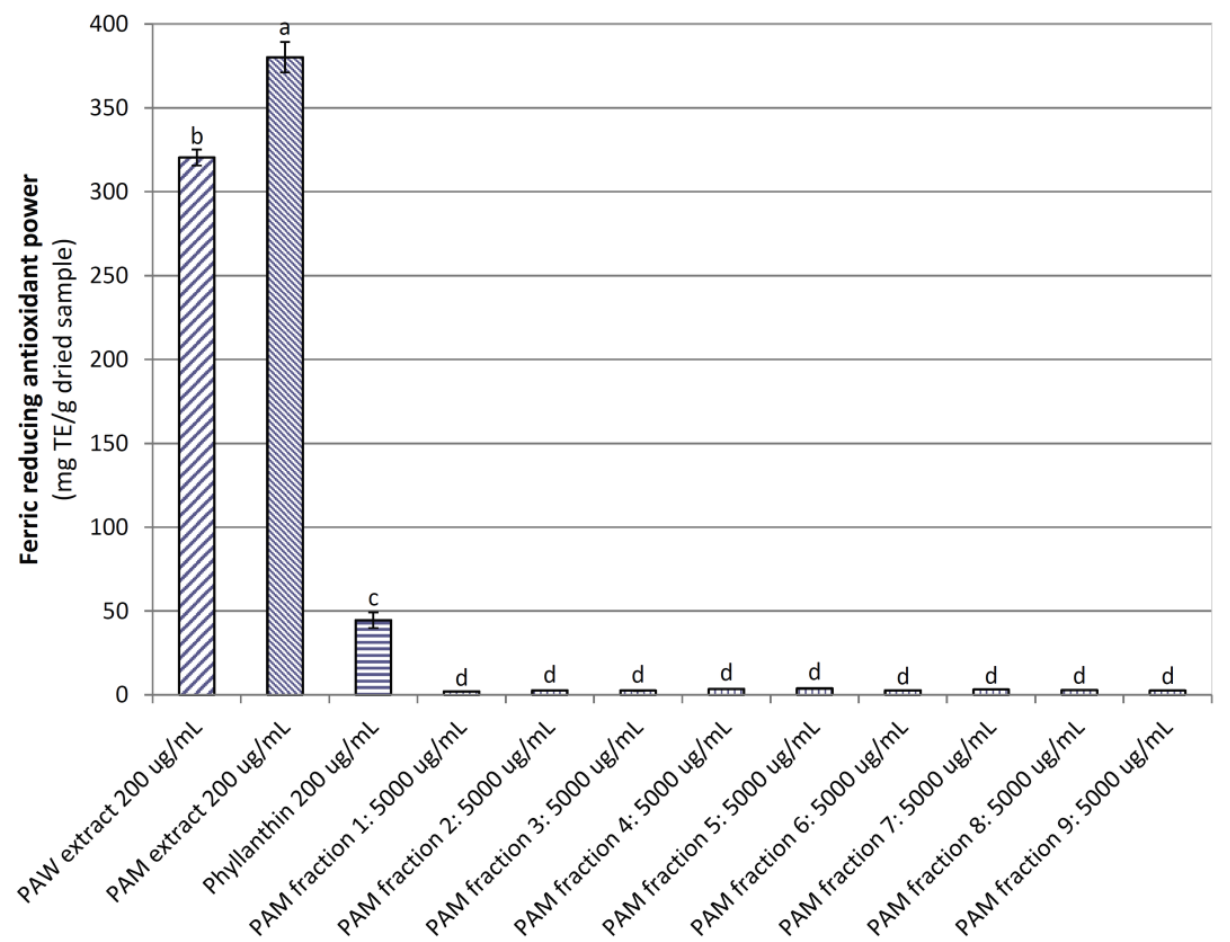

Figure 4. Ferric reducing antioxidant power of powdered the P. amarus water (PAW) and methanol (PAM) extracts and PAM fractions. Phyllanthin was used as a positive control. Different letters within the columns denotes a significant difference between treatments $(p<0.05)$. 
The findings from this study indicated that the $P A$ extracts displayed potent antioxidant activity against free radicals and for reducing ferric ion, while all fractions from the PAM extract exhibited weak antioxidant capacity. This may be due to a loss of activity of the PAM fractions during the fractionation, evaporation, and drying processes by the oxidation and decomposition of sensitive bioactive compounds under the effect of UV light, oxygen in the environment, and/or the deterioration of key bioactive compounds by concentrated orthophosphoric acid remaining in the fractions. Therefore, the PA extracts are considered as a promising source for the development of potential antioxidant products.

\subsection{Cytotoxic Potential of Powdered P. amarus Extracts and Fractions}

\subsubsection{Growth Inhibition of Cancer Cell Lines by PA Extracts}

Table 2 shows the cell growth inhibition of the $P A$ extracts on twelve cell lines, including MiaPaCa-2 (pancreas), HT29 (colon), A2780 (ovarian), H460 (lung), A431 (skin), Du145 (prostate), BE2-C (neuroblastoma), MCF-7 (breast), MCF-10A (normal breast), and U87, SJ-G2, SMA (glioblastoma). At a dose of $100 \mu \mathrm{g} / \mathrm{mL}$, cell growth inhibition of the PAM extract on all cell lines was much higher than that of the PAW extract, likely due to the PAM extract possessing much higher contents of saponins, phenolics, flavonoids, and proanthocyanidins when compared to the PAW extract.

Table 2. Cytotoxic capacity of powdered P. amarus (PA) extracts on different cancer cell lines

\begin{tabular}{|c|c|c|}
\hline \multirow[t]{2}{*}{ Cancer Cell Line (Cell Type) } & \multicolumn{2}{|c|}{$\begin{array}{c}\% \text { Cell Growth Inhibition } \\
\text { at } 100 \mu \mathrm{g} / \mathrm{mL} \text { of } P A \text { Extracts }(n=3-6)\end{array}$} \\
\hline & Water (PAW) Extract & Methanol (PAM) Extract \\
\hline MiaPaCa2 (pancreas) & $38 \pm 5$ & $48 \pm 3$ \\
\hline HT29 (colon) & $23 \pm 3$ & $49 \pm 7$ \\
\hline A2780 (ovarian) & $46 \pm 4$ & $74 \pm 3$ \\
\hline H460 (lung) & $16 \pm 5$ & $53 \pm 3$ \\
\hline A431 (skin) & $31 \pm 1$ & $74 \pm 2$ \\
\hline Du145 (prostate) & $26 \pm 8$ & $73 \pm 3$ \\
\hline BE2-C (neuroblastoma) & $51 \pm 14$ & $54 \pm 4$ \\
\hline MCF-7 (breast) & $16 \pm 4$ & $67 \pm 8$ \\
\hline MCF-10A (breast-normal) & $43 \pm 7$ & $73 \pm 2$ \\
\hline U87 (glioblastoma) & $23 \pm 6$ & $62 \pm 10$ \\
\hline SJ-G2 (glioblastoma) & $28 \pm 1$ & $54 \pm 10$ \\
\hline SMA (glioblastoma-murine) & $49 \pm 18$ & $31 \pm 13$ \\
\hline
\end{tabular}

Cell growth inhibition of the PAM extract achieved in this study was comparable to those of the extracts from E. robusta leaf [28] and maroon bush (S. spinescens) [38], but it was weaker than those from P. trimera root [4] and leaf [7]. Lee at el. [19] evaluated the anti-metastatic potential of Phyllanthus spp. (P. niruri, P. urinaria, P. watsonii, and P. amarus) on lung (A549) and breast (MCF-7) carcinoma cells and found that Phyllanthus extracts effectively reduced invasion, migration, and adhesion for both MCF-7 and A549 cells at concentrations ranging from 20-200 and 50-500 $\mathrm{gg} / \mathrm{mL}$ for methanolic and aqueous extracts, respectively, while Abhyankar et al. [20] determined the cytotoxic effects of the methanolic extract from $P$. amarus hairy roots on the human breast adenocarcinoma cell line (MCF-7) and a cervical cancer cell line (HeLa), and indicated that the cytotoxicity correlated well with the increased levels of intracellular reactive oxygen species (ROS) and decreased mitochondrial membrane potential, particularly an appreciable anti-proliferative effect of the $P$. amarus hairy root extract on the MCF-7 cells was recorded via induction of apoptosis. Lawson-Evi et al. [18] also reported that the aqueous extract of $P$. amarus was more cytotoxic on human colon cancer cells (Caco-2) than a hydroalcoholic extract, with $\mathrm{IC}_{50}$ values being $89.6 \mu \mathrm{g} / \mathrm{mL}$ and $277 \mu \mathrm{g} / \mathrm{mL}$ for the $P$. amarus aqueous and hydroalcoholic extracts, respectively. 
The outcomes obtained from this study allow further application of the PAM extract alone or in combination with other agents for the development of novel anti-cancer drugs.

3.4.2. Viability of Pancreatic Cancer and Normal Cells by treatment with P. amarus Methanol (PAM) Extract and Its Fractions

Figure 5 shows the cell viability of pancreatic cancer cells MiaPaCa2 treated with various concentrations of the PAM extract $(200-12.5 \mu \mathrm{g} / \mathrm{mL})$, nine fractions from the PAM extract $(50 \mu \mathrm{g} / \mathrm{mL})$, phyllanthin $(2 \mu \mathrm{g} / \mathrm{mL})$, gemcitabine $(50 \mathrm{nM})$, and quillaja bark extract $(200 \mu \mathrm{g} / \mathrm{mL})$. At $200 \mu \mathrm{g} / \mathrm{mL}$ of the PAM extract, cell viability of MiaPaCa2 cells $(72.58 \%)$ was significantly lower $(p<0.05)$ than those at lower concentrations of $100-12.5 \mu \mathrm{g} / \mathrm{mL}(91.15-97.90 \%), 50 \mu \mathrm{g} / \mathrm{mL}$ of nine PAM fractions (75.24-95.42\%), and $2 \mu \mathrm{g} / \mathrm{mL}$ of phyllanthin $(95.67 \%)$, but it was significantly higher $(p<0.05)$ than those of $50 \mathrm{nM}$ of gemcitabine (27.22\%) and quillaja bark extract at $200 \mu \mathrm{g} / \mathrm{mL}(4.20 \%)$. This indicated that a component in fraction 6 might have a great contribution to the cytotoxicity on MiaPaCa2 cells of the PAM extract. Therefore, fraction 6 should be purified and characterized in further studies. Cell viability of MiaPaCa2 cells treated with $200 \mu \mathrm{g} / \mathrm{mL}$ of the PAM extract in this study was much higher than those treated with $200 \mu \mathrm{g} / \mathrm{mL}$ of lilly pilly (S. paniculatum) extract [39] (about 23\%), $200 \mu \mathrm{g} / \mathrm{mL}$ or water and methanol E. tirucalli extracts (approximately 30 and $7.0 \%$, respectively) [37] and $200 \mu \mathrm{g} / \mathrm{mL}$ of methanol extracts from P. trimera root [4] and leaf [7] (4.2 and 6.6\%, respectively).

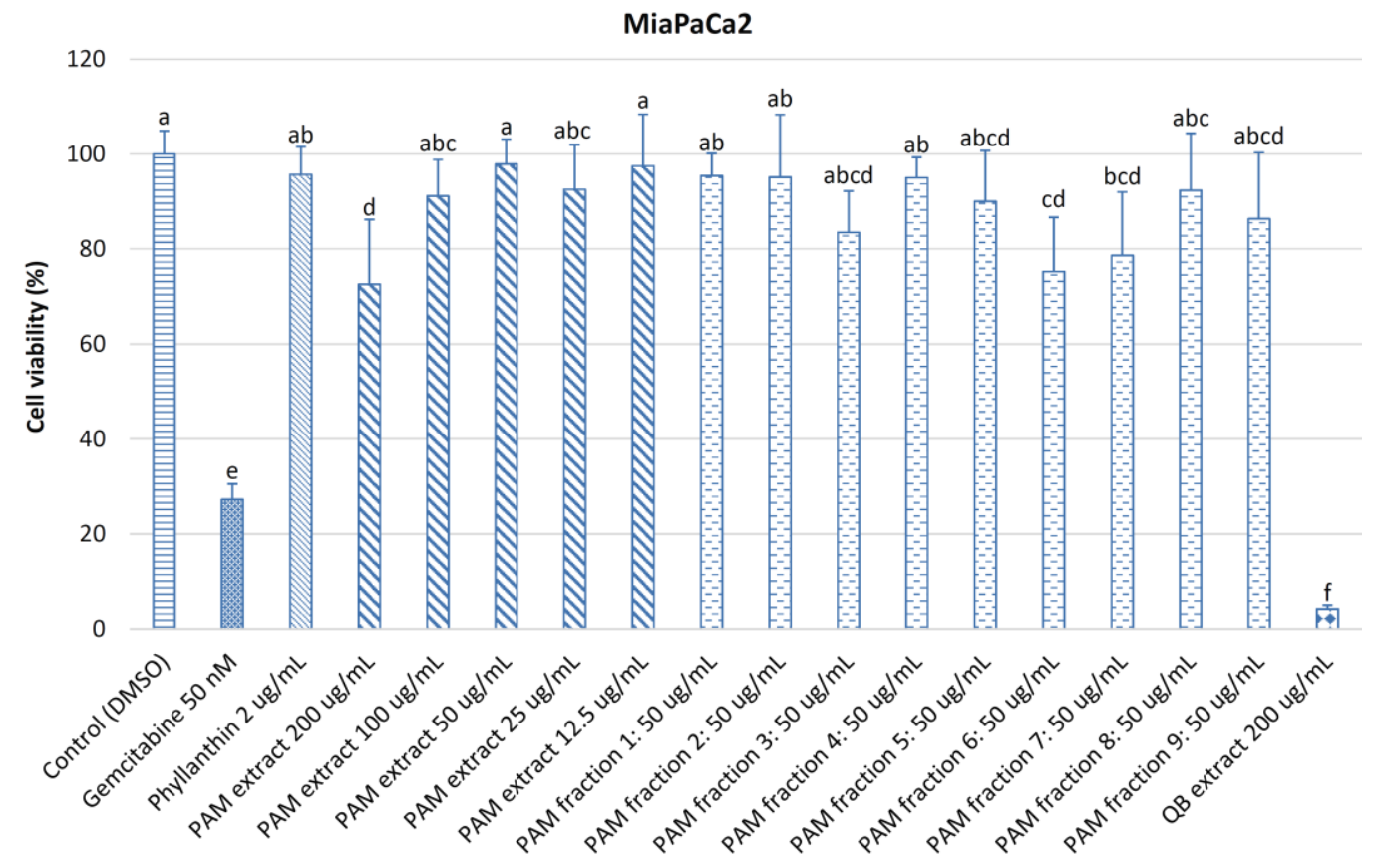

Figure 5. Viability of MiaPaCa2 cells treated with different concentrations of powdered P. amarus methanol (PAM) extract and fractions. DMSO was used as a control; gemcitabine and phyllanthin were used as positive controls; and quillajia bark (QB) extract was used as a comparative sample. Different letters within the columns denotes a significant difference between treatments $(p<0.05)$.

Figure 6 indicates that the cell viability of normal human pancreatic ductal epithelial (HPDE) cells treated with 200 and $100 \mu \mathrm{g} / \mathrm{mL}$ of the PAM extract (2.18 and $10.61 \%$, respectively), $50 \mathrm{nM}$ of gemcitabine $(2.37 \%)$, and $200 \mu \mathrm{g} / \mathrm{mL}$ of quillaja bark extract $(1.88 \%)$ was significantly lower $(p<0.05)$ than those treated with the PAM extract at $50-12.5 \mu \mathrm{g} / \mathrm{mL}(66.20-98.57 \%)$, nine fractions from the PAM extract $(100.85-111.14 \%)$, and phyllanthin $(99.91 \%)$, revealing that the nine fractions isolated from the PAM extract (except fraction 6) exhibited weak activity on MiaPaCa2 and HPDE cells. The reason for this may be due to a loss of activity of the PAM fractions during the fractionation, evaporation, and 
drying processes by the oxidation and decomposition of sensitive bioactive compounds under the effect of UV light and oxygen in the environment and / or the deterioration of key bioactive compounds by concentrated orthophosphoric acid remaining in the fractions. Low cytotoxicity on HPDE cells of the PAM fractions is a prominent advantage for further applications. The cell viability of HPDE cells treated with $100 \mu \mathrm{g} / \mathrm{mL}$ of the PAM extract found in this study $(10.61 \%)$ was much lower than that treated with $100 \mu \mathrm{g} / \mathrm{mL}$ of S. paniculatum extract [39] (58\%) but it was much higher than those treated with $100 \mu \mathrm{g} / \mathrm{mL}$ of methanol extracts from P. trimera root [4] and leaf [7] (2.4 and 2.2\%, respectively). The PAM extract greatly affected cell growth of MiaPaCa2 and HPDE cells as it was rich in saponins, phenolics, flavonoids, and proanthocyanidins.

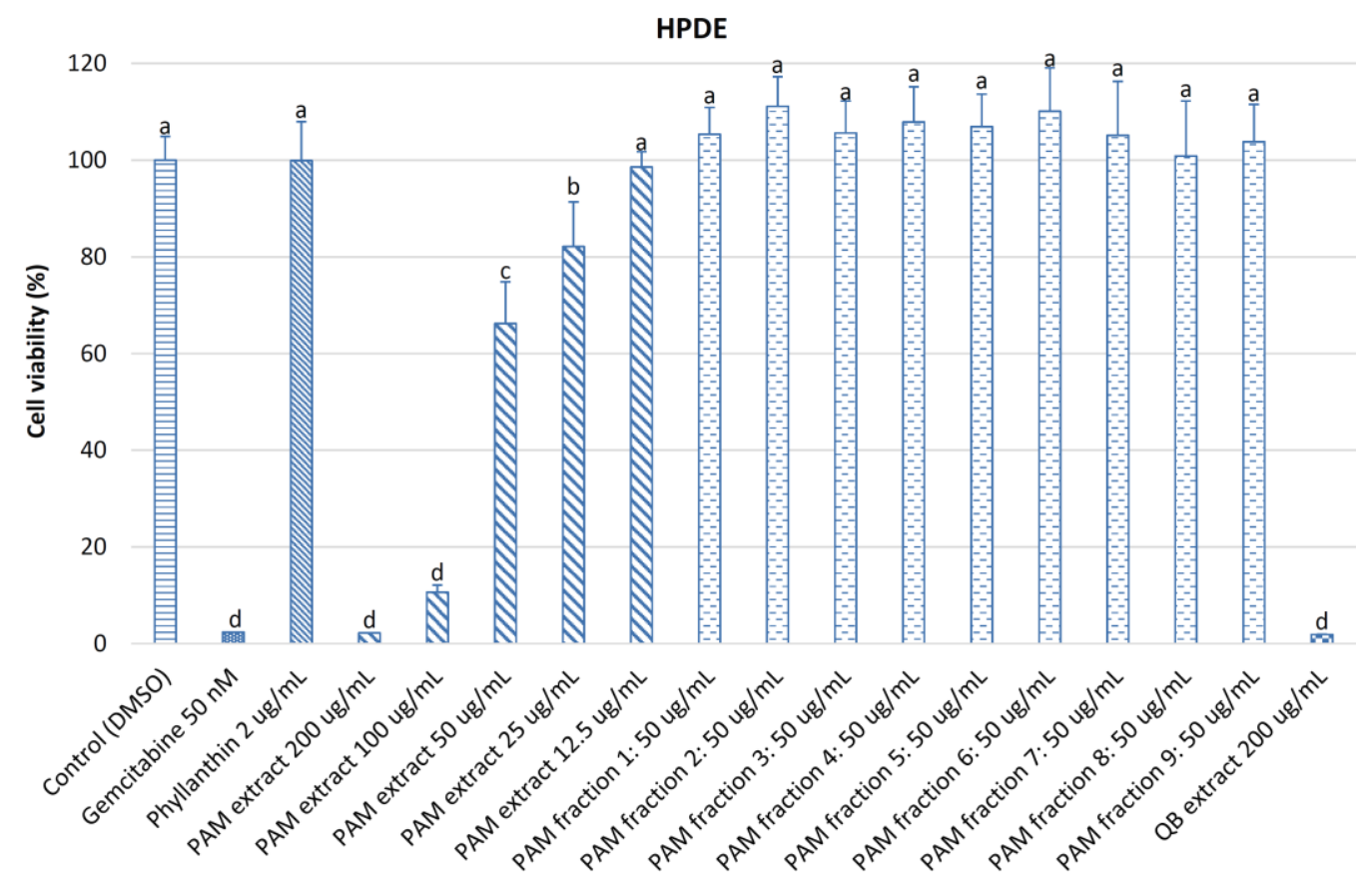

Figure 6. Viability of HPDE cells treated with different concentrations of powdered P. amarus methanol $(P A M)$ extract and fractions. DMSO was used as a control; gemcitabine and phyllanthin were used as positive controls; and quillajia bark (QB) extract was used as a comparative sample. Different letters within the columns denotes a significant difference between treatments $(p<0.05)$.

This is the first report describing the effect of the PAM extract against pancreatic cancer cells, therefore further study should be continued to evaluate the anti-pancreatic cancer potential of the PAM extract on other pancreatic cancer cell lines, as well as to understand the mechanism of action of the $P A M$ extract on these pancreatic cancer cell lines.

\section{Conclusions}

This study showed the great antioxidant potential of the $P A$ extracts in vitro, in which the PAM extract processed higher antioxidant and cytotoxic capacities as compared to the PAW extract. In addition, the antioxidant and cytotoxic activities of the crude $P A$ extracts were stronger than those of the fractions. Therefore, we can conclude that the $P A$ extracts are a promising source for further applications in the nutraceutical, medical, and pharmaceutical industries for the development of natural antioxidant products.

Acknowledgments: We kindly thank the funding support from the Faculty of Science, University of Newcastle, Australia. The VIED-TUIT scholarship for Van Tang Nguyen from Vietnamese Government through the Vietnam International Education Development-Ministry of Education and Training (Project 911) and the University of Newcastle is gratefully acknowledged. 
Author Contributions: Van Tang Nguyen and Jennette A. Sakoff conceived, designed and performed the experiments. Van Tang Nguyen analyzed the data and wrote the paper. Jennette A. Sakoff and Christopher J. Scarlett reviewed and corrected the paper. Van Tang Nguyen revised the paper.

Conflicts of Interest: The authors declare no conflict of interest.

\section{References}

1. Li, L.; Leung, P.S. Use of herbal medicines and natural products: An alternative approach to overcoming the apoptotic resistance of pancreatic cancer. Int. J. Biochem. Cell Biol. 2014, 53, 224-236. [CrossRef] [PubMed]

2. Jamieson, N.B.; Grimmond, S.M.; Biankin, A.V.; Chang, D.K.; Initiative, A.P.C.G. Pancreatic cancer: challenges for therapeutic development. In Plant Bioactive Compounds for Pancreatic Cancer Prevention and Treatment; Scarlett, C.J., Vuong, Q.V., Eds.; Nova Science Publishers: Hauppauge, NY, USA, 2014; pp. 1-27.

3. Ji, X.; Usman, A.; Razalli, N.H.; Sambanthamurthi, R.; Gupta, S.V. Oil palm phenolics (OPP) inhibit pancreatic cancer cell proliferation via suppression of NF-кB pathway. Anticancer Res. 2015, 31, 97-106.

4. Nguyen, V.T.; Sakoff, J.A.; Scarlett, C.J. Physicochemical, antioxidant and cytotoxic properties of Xao tam phan (Paramignya trimera) root extract and its fractions. Chem. Biodivers. 2017, 14. [CrossRef] [PubMed]

5. Pozza, E.D.; Donadelli, M.; Costanzo, C.; Zaniboni, T.; Dando, I.; Franchini, M.; Arpicco, S.; Scarpa, A.; Palmieri, M. Gemcitabine response in pancreatic adenocarcinoma cells is synergistically enhanced by dithiocarbamate derivatives. Free Rad. Biol. Med. 2011, 50, 926-933. [CrossRef] [PubMed]

6. Graham, J.S.; Jamieson, N.B.; Rulach, R.; Grimmond, S.M.; Chang, D.K.; Biankin, A.V. Pancreatic cancer genomics: where can the science take us? Clin. Gen. 2015. [CrossRef] [PubMed]

7. Nguyen, V.T.; Sakoff, J.A.; Scarlett, C.J. Physicochemical properties, antioxidant and anti-proliferative capacities of dried leaf and its extract from Xao tam phan (Paramignya trimera). Chem. Biodivers. 2017. [CrossRef] [PubMed]

8. Newman, D.J.; Cragg, G.M. Natural products as sources of new drugs over the last 25 years. J. Nat. Prod. 2007, 70, 461-477. [CrossRef] [PubMed]

9. Colvin, E.K. History and development of plant-derived anti-cancer agents. In Plant Bioactive Compounds for Pancreatic Cancer Prevention and Treatment; Scarlett, C.J., Vuong, Q.V., Eds.; Nova Science Publishers: Hauppauge, NY, USA, 2014; pp. 29-43.

10. Pengelly, A. Traditional use of plants as folk medicine. In Plant Bioactive Compounds for Pancreatic Cancer Prevention and Treatment; Scarlett, C.J., Vuong, Q.V., Eds.; Nova Science Publishers: Hauppauge, NY, USA, 2014; pp. 46-58.

11. Igwe, C.U.; Nwaogu, L.A.; Ujuwondu, C.O. Assessment of the hepatic effects, phytochemical and proximate compositions of Phyllanthus amarus. Afr. J. Biotechnol. 2007, 6, 728-731.

12. Patel, J.R.; Tripathib, P.; Sharmaa, V.; Chauhana, N.S.; Dixit, V.K. Phyllanthus amarus: Ethnomedicinal uses, phytochemistry and pharmacology: A review. J. Ethnopharmarcol. 2011, 138, 286-313. [CrossRef] [PubMed]

13. Nikam, P.S.; Nikam, S.V.; Sontakke, A.V. Lipid peroxidation and antioxidants during treatment of hepatitis -b with Phyllanthus amarus. Int. J. Biol. Med. Res. 2010, 1, 41-43.

14. Nikam, P.S.; Nikam, S.V.; Sontakke, A.V.; Khanwelkar, C.C. Role of Phyllanthus amarus treatment in Hepatitis-C. Biomed. Res. 2011, 22, 319-322.

15. Nguyen, V.T.; Vuong, Q.V.; Bowyer, M.C.; van Altena, I.A.; Scarlett, C.J. Effects of different drying methods on bioactive compound yield and antioxidant capacity of Phyllanthus amarus. Dry. Technol. J. 2015, 33, 1006-1017. [CrossRef]

16. Nguyen, V.T.; Pham, H.N.T.; Bowyer, M.C.; van Altena, I.A.; Scarlett, C.J. Influence of solvents and novel extraction methods on bioactive compounds and antioxidant capacity of Phyllanthus amarus. Chem. Pap. 2016, 70, 556-566. [CrossRef]

17. Nguyen, V.T.; Bowyer, M.C.; van Altena, I.A.; Scarlett, C.J. Optimisation of microwave-assisted extraction from Phyllanthus amarus for phenolic compounds-enriched extracts and antioxidant capacity. Chem. Pap. 2016, 70, 713-725. [CrossRef]

18. Lawson-Evi, P.; Eklu-Gadegbeku, K.; Agbonon, A.; Aklikokou, K.; Moukha, S.; Creppy, E.E.; Gbéassor, M. Toxicological assessment on extracts of Phyllanthus amarus Schum and thonn. Sci. Res. Essays 2008, 3, 410-415.

19. Lee, S.H.; Jaganath, I.B.; Wang, S.M.; Sekaran, S.D. Antimetastatic effects of Phyllanthus on human lung (A549) and breast (MCF-7) cancer cell lines. PLoS ONE 2011, 6, e20994. [CrossRef] [PubMed] 
20. Abhyankar, G.; Suprasanna, P.; Pandey, B.N.; Mishra, K.P.; Rao, K.V.; Reddy, V.D. Hairy root extract of Phyllanthus amarus induces apoptotic cell death in human breast cancer cells. Innov. Food Sci. Emerg. Technol. 2010, 11, 526-532. [CrossRef]

21. Poompachee, K.; Chudapongse, N. Comparison of the antioxidant and cytotoxic activities of Phyllanthus virgatus and Phyllanthus amarus extracts. Med. Principl. Prac. 2011, 21, 24-29. [CrossRef] [PubMed]

22. Association of Official Analytical Chemists (AOAC). Official Methods of Analysis, 16th ed.; Association of Official Analytical Chemists: Washington, DC, USA, 1998.

23. Nguyen, V.T.; Vuong, Q.V.; Bowyer, M.C.; van Altena, I.A.; Scarlett, C.J. Microwave-assisted extraction for saponins and antioxidant capacity from Xao tam phan (Paramignya trimera) root. J. Food Process. Preserv. Early View 2016. [CrossRef]

24. Vuong, Q.V.; Hirun, S.; Roach, P.D.; Bowyer, M.C.; Phillips, P.A.; Scarlett, C.J. Effect of extraction conditions on total phenolic compounds and antioxidant activities of Carica papaya leaf aqueous extracts. J. Herb. Med. 2013, 3, 104-111. [CrossRef]

25. Nguyen, V.T.; Pham, N.M.Q.; Vuong, Q.V.; Bowyer, M.C.; van Altena, I.A.; Scarlett, C.J. Phytochemical retention and antioxidant capacity of Xao tam phan (Paramignya trimera) root as prepared by different drying methods. Dry. Technol. J. 2016, 34, 324-334. [CrossRef]

26. Kamonwannasit, S.; Nantapong, N.; Kumkrai, P.; Luecha, P.; Kupittayanant, S.; Chudapongse, N. Antibacterial activity of Aquilaria crassna leaf extract against Staphylococcus epidermidis by disruption of cell wall. Ann. Clin. Microbiol. Antimicro. 2013, 12, 1-7. [CrossRef] [PubMed]

27. Pisoschi, A.M.; Negulescu, G.P. Methods for total antioxidant activity determination: a review. Biochem. Anal. Biochem. 2011, 1, 1-10. [CrossRef]

28. Vuong, Q.V.; Hirun, S.; Chuen, T.L.K.; Goldsmith, C.D.; Munro, B.; Bowyer, M.C.; Chalmers, A.C.; Sakoff, J.A.; Phillips, P.A.; Scarlett, C.J.; et al. Physicochemical, antioxidant and anti-cancer activity of a Eucalyptus robusta (Sm.) leaf aqueous extract. Ind. Crops Prod. 2015, 64, 167-174. [CrossRef]

29. Tan, S.P.; Vuong, Q.V.; Stathopoulos, C.E.; Parks, S.E.; Roach, P.D. Optimized aqueous extraction of saponins from bitter melon for production of a saponin-enriched bitter melon powder. J. Food Sci. 2014, 79, E1372-E1381. [CrossRef] [PubMed]

30. Chirife, J.; Fontana, A.J. Introduction: Historical highlights of water activity research. In Water Activity in Foods: Fundamentals and Applications; Barbosa-Cánovas, G.V., Fontana, A.J., Schmidt, S.J., Labuza, T.P., Eds.; Blackwell Publishing: Iowa, IA, USA, 2008; pp. 3-13.

31. Pham, H.N.T.; Nguyen, V.T.; Vuong, Q.V.; Bowyer, M.C.; Scarlett, C.J. Bioactive compound yield and antioxidant capacity of Helicteres hirsuta Lour. stem as affected by various solvents and drying methods. J. Food Process. Preserv. 2016, 41, 1-9. [CrossRef]

32. Man, S.; Gao, W.; Zhang, Y.; Huang, L.; Liu, C. Chemical study and medical application of saponins as anti-cancer agents. Fitoterapia 2010, 81, 703-714. [CrossRef] [PubMed]

33. Vuong, Q.V.; Hirun, S.; Chuen, T.L.K.; Goldsmith, C.D.; Murchie, S.; Bowyer, M.C.; Phillips, P.A.; Scarlett, C.J. Antioxidant and anticancer capacity of saponin-enriched Carica papaya leaf extracts. Int. J. Food Sci. Technol. 2015, 50, 169-177. [CrossRef]

34. Doughari, J.H. Phytochemicals-a global perspective of their role in nutrition and health. In Phytochemicals: Extraction Methods, Basic Structures and Mode of Action as Potential Chemotherapeutic Agents; Rao, V., Ed.; InTech Europe: Rijeka, Croatia, 2012; pp. 1-32.

35. Nguyen, V.T.; Bowyer, M.C.; Vuong, Q.V.; van Altena, I.A.; Scarlett, C.J. Phytochemicals and antioxidant capacity of Xao tam phan (Paramignya trimera) root as affected by various solvents and extraction methods. Ind. Crops Prod. 2015, 67, 192-200. [CrossRef]

36. Krithika, R.; Mohankumar, R.; Verma, R.J.; Shrivastav, P.S.; Mohamad, I.L.; Gunasekaran, P.; Narasimhan, S. Isolation, characterization and antioxidative effect of phyllanthin against CCl4-induced toxicity in HepG2 cell line. Chem.-Biol. Interact. 2009, 181, 351-358. [CrossRef] [PubMed]

37. Munro, B.; Vuong, Q.V.; Chalmers, A.C.; Goldsmith, C.D.; Bowyer, M.C.; Scarlett, C.J. Phytochemical, antioxidant and anti-cancer properties of Euphorbia tirucalli methanolic and aqueous extracts. Antioxidants 2015, 4, 647-661. [CrossRef] [PubMed]

38. Vuong, Q.V.; Sadeqzadeh, E.; Hirun, S.; Goldsmith, C.D.; Zammitt, N.; Bowyer, M.C.; Sakoff, J.A.; Thorne, R.F.; Weidenhofer, J.; Scarlett, C.J.; et al. Phenolic compounds, antioxidant and anti-cancer properties of the Australian maroon bush scaevola spinescens (Goodeniaceae). J. Bioanal. Biomed. 2015, S12. [CrossRef] 
39. Vuong, Q.V.; Hiruna, S.; Chuen, T.L.K.; Goldsmith, C.D.; Bowyer, M.C.; Chalmers, A.C.; Phillips, P.A.; Scarlett, C.J. Physicochemical composition, antioxidant and anti-proliferative capacity of a lilly pilly (Syzygium paniculatum) extract. J. Herb. Med. 2014, 4, 134-140. [CrossRef] 